\title{
Identification of 118 Arabidopsis Transcription Factor and 30 Ubiquitin-Ligase Genes Responding to Chitin, a Plant-Defense Elicitor
}

\author{
Marc Libault, ${ }^{1}$ Jinrong Wan, ${ }^{1}$ Tomasz Czechowski, ${ }^{2}$ Michael Udvardi, ${ }^{2}$ and Gary Stacey ${ }^{1}$ \\ ${ }^{1}$ National Center for Soybean Biotechnology, Divisions of Plant Science and Biochemistry, Department of Molecular \\ Microbiology and Immunology, Christopher S. Bond Life Sciences Center, University of Missouri, Columbia, MO 65211, \\ U.S.A.; ${ }^{2}$ Max-Planck Institute of Molecular Plant Physiology, Potsdam, Germany
}

Submitted 17 January 2007. Accepted 7 March 2007.

Chitin, found in the cell walls of true fungi and the exoskeleton of insects and nematodes, is a well-established elicitor of plant defense responses. In this study, we analyzed the expression patterns of Arabidopsis thaliana transcription factor (TF) and ubiquitin-ligase genes in response to purified chitooctaose at different treatment times (15, $30,60,90$, and $120 \mathrm{~min}$ after treatment), using both quantitative polymerase chain reaction and the Affymetrix Arabidopsis whole-genome array. A total of $118 \mathrm{TF}$ genes and 30 ubiquitin-ligase genes were responsive to the chitin treatment. Among these genes, members from the following four TF families were overrepresented: APETALA2/ethylenereponsive element binding proteins (27), $\mathrm{C} 2 \mathrm{H} 2$ zinc finger proteins (14), MYB domain-containing proteins (11), and WRKY domain transcription factors (14). Transcript variants from a few of these genes were found to respond differentially to chitin, suggesting transcript-specific regulation of these TF genes.

Additional keyword: PAMP

In nature, plants are confronted by a variety of pathogens and pests. As part of their innate immune system, plants recognize these invaders by virtue of pathogen-associated molecular patterns (PAMP), cellular substituents common to a variety of pathogens (Nürnberger et al. 2004). PAMP include such molecules as flagellin (Felix et al. 1999; Gomez-Gomez 2004) and various oligosaccharides, including chitin. Recognition of the PAMP results in the induction (elicitation) of various pathogen defense pathways in the plant.

Recognition of pathogen elicitors by the plant can induce hypersensitive cell death and synthesis of antimicrobial molecules (phytoalexins; Heath 2000). For example, volicitin (Schmelz et al. 2003) and flagellin (Zipfel et al. 2004) activate the pathways mediated by jasmonic acid (JA) and ethylene (ET), two plant hormones with a major role in plant pathogen defense. Activation of these pathways also results in the synthesis of a variety of proteins (pathogenesis-related [PR] proteins) thought to play a role in pathogen defense. One such ex-

Corresponding author: M. Libault; E-mail: libaultm@missouri.edu

Microarray sequence data has been deposited in the NCBI Gene Expression Omnibus database. The accession number for the data set is GSE4746.

* The $\boldsymbol{e}$-Xtra logo stands for "electronic extra" and indicates supplemental material is published online. Seven additional tables are available online. ample is chitinase, an enzyme that catalyzes the hydrolysis of chitin polymers, composed of $\beta$ - $1 \rightarrow 4$-linked $N$-acetylglucosamine, found in the cell walls of pathogenic fungi and in the exoskeleton of insects and nematodes (Shibuya and Minami 2001). Application of purified chitin oligomers from different sources (such as yeast and crab shell) to plants or their cell cultures was shown to elicit various defense-related reactions, such as activation of PR genes and synthesis of phytoalexins (Shibuya and Minami 2001; Stacey and Shibuya 1997). DNA microarray analysis showed a large number of Arabidopsis thaliana genes induced upon chitin elicitation (Ramonell et al. 2002, 2005; Zhang et al. 2002). Comparison of the response of wild-type Arabidopsis with various mutants blocked in the ET, salicylic acid (SA), and JA signaling pathways showed that the initial response to chitin elicitation was independent of these pathways, suggesting a unique pathway for chitin action (Zhang et al. 2002). Initial activation of a mitogen-activated protein kinase cascade is important to chitin elicitation (Wan et al. 2004). A criticism often leveled against research dealing with PAMP is that elicitor action is not always related to pathogen virulence. However, in the case of chitin, Ramonell and associates (2005) showed that mutations in some genes identified by microarray analysis as responsive to chitin resulted in increased susceptibility to the powdery mildew fungal pathogen Erysiphe cichoracearum. Chitin pretreatment of plants also reduces susceptibility to subsequent fungal pathogen challenge (Tanabe et al. 2006). Thus, chitin elicitation appears to play a significant role in plant defense to fungal pathogens.

Structure-function analysis in a variety of plants showed that larger chitin oligomers (degree of polymerization (d.p.) $=7$ to 8 $\mathrm{N}$-acetylglucosamine residues) were most effective as elicitors (Shibuya and Minami 2001; Stacey and Shibuya 1997). A number of membrane-associated chitin-binding proteins, presumably chitin receptors, were previously identified in a variety of plants, such as soybean (Day et al. 2001), French bean (Bindschedler et al. 2006), and tomato (Baureithel et al. 1994). Recently, Kaku and associates (2006) identified the likely chitin receptor in rice as a protein with one transmembrane domain and with two predicted, extracellular LysM domains. Extracellular LysM domains are also found in those proteins predicted to be the plant receptors for the lipo-chitin nodulation factors produced by rhizobium and essential for legume nodulation (Stacey et al. 2006).

The fact that chitin elicits de novo gene expression suggests the involvement of transcription factors (TF). DNA microarray studies have greatly expanded the list of TF that are responsive to pathogen inoculation and other treatments. Among the tran- 
scription factor families implicated in plant disease resistance are the AP2-ERE (Kim et al. 2000; McGrath et al. 2005), C2H2 zinc finger (McGrath et al. 2005), MYB (Hui et al. 2003; Liu et al. 2004; McGrath et al. 2005; Yang and Klessig 1996; Vailleau et al. 2002), WRKY (Hui et al. 2003; Kim and Zhan 2004; Liu et al. 2004, 2005; McGrath et al. 2005; Park et al. 2006; Ramonell et al. 2005; Ryu et al. 2006; Wan et al. 2004), GRAS (Day et al. 2003, 2004), bZIP (Thurow et al. 2005), NAC domain-containing (McGrath et al. 2005), Whirly (Desveaux et al. 2005), DOF (McGrath et al. 2005; Yanagisawa 2002), and MYC (Boter et al. 2004; Lorenzo et al. 2004) families. However, mRNAs for TF are often present in relatively low levels in cells, and DNA microarray hybridizations do a poor job in accurately measuring such low abundant mRNAs. To address these issues, Czechowski and associates (2004) designed 2,297 quantitative polymerase chain reaction (qPCR) primers for all the potential 2,077 $\mathrm{TF}$ genes and 150 putatitve ubiquitin-ligase genes in A. thaliana. Their results suggest that qPCR measurement of TF expression is at least 100 -fold more sensitive than DNA microarray hybridization (Czechowski et al. 2004; McGrath et al. 2005).

In our current study, we utilized the Arabidopsis TF qPCR primer set for transcriptional profiling of TF gene expression after elicitation with chitooctaose $(d . p .=8)$. These results were directly compared with data derived from hybridization to the Affymetrix Arabidopsis genome array. In addition to TF genes, we also examined the response of some ubiquitin-ligase genes to chitin, due to their probable role in plant defense (Liu et al. 2002; Yang et al. 2006). Collectively, these methods identified 118 TF genes and 30 ubiquitin-ligase genes to be responsive to chitooctaose. During the analysis, it became apparent that some genes expressed more than one transcript and, in a few such cases, a transcript-specific response to chitooctaose was seen.

\section{RESULTS}

Arabidopsis genes regulated by chitooctaose: a summary.

We sought to identify the TF genes involved in the response to chitooctaose, a main elicitor of the plant defense response against pathogens. In order to establish the most complete list of chitin-responsive TF genes, we used two different technologies, high-throughput (quantitative reverse transcription) qRT-PCR and microarray hybridization. Collectively, these two technologies allowed us to identify 118 Arabidopsis TF genes responding after 15 or $30 \mathrm{~min}$ of chitooctaose treatment. These $118 \mathrm{TF}$ genes represent $29 \mathrm{TF}$ families. The same experiments identified 30 ubiquitin-ligase genes as responsive to chitin elicitation. As described below, these gene lists were compiled not only by comparison of both the qRT-PCR and microarray results but also by resolving discrepancies between the two data sets.

\section{TF responding to chitooctaose.}

We measured the expression profile of 2,077 Arabidopsis thaliana TF genes by qRT-PCR, utilizing the 2,146 primer set library (Czechowski et al. 2004). Three independent experiments were done using Arabidopsis seedlings treated with chitooctaose or mock-treated with water for 15 or $30 \mathrm{~min}$. These experiments identified $99 \mathrm{TF}$ that responded significantly to chitooctaose elicitation (Table 1) (the complete set of qRTPCR data from these experiments is available as Supplemental Table I).

Using the same RNA as used above, we also profiled the transcriptional response of Arabidopsis to $30 \mathrm{~min}$ of chitooctaose treatment utilizing the Arabidopsis Affymetrix DNA microarray. This data set identified an additional 19 Arabidopsis TF genes as responsive to chitooctaose treatment. Microarray results were confirmed by qRT-PCR analysis using RNA samples from 15 and 30 min after chitin treatment (Table 1).

Taken together, out of the 118 genes identified by the highthroughput qRT-PCR and Affymetrix hybridization, 61 and 106 TF genes were significantly down- or up-regulated $(P$ value $<0.05$ and fold change $<0.5$ or $>2$ ) 15 and 30 min after chitooctaose treatment (Table 1). These chitooctaose-responsive genes represent 19 and 26 different families, respectively, based on their functional domains. Most of the responsive genes were up-regulated after chitooctaose treatment (59 and 101, respectively, after 15 and $30 \mathrm{~min}$ of chitin treatment). A total of $49 \mathrm{TF}$ genes were up-regulated both 15 and $30 \mathrm{~min}$ after chitooctaose treatment.

When compared with the gene family distribution of the primer set library used for qRT-PCR expression analysis (we consider this library as representative of the TF genes existing in Arabidopsis; 75 different families with nine families representing more than $50 \%$ of the library [Fig. 1, top; Supplemental Table II]), four TF families were significantly overrepresented in the $118 \mathrm{TF}$ genes that responded to chitin treatment. These included the APETALA2/ET-reponsive element binding protein (AP2/ERE), C2H2 zinc finger, MYB domain transcription factor, and WRKY domain transcription factor families. These four families represent $28.8 \%$ of the qPCR primer library (Fig. 1, top) but represent $62.3 \%$ (38 TF genes) of those that responded after $15 \mathrm{~min}$ of treatment and 57.6\% (61 TF genes) of those responding after $30 \mathrm{~min}$ (Fig. 1, bottom).

\section{Chitooctaose strongly affects TF gene expression after 30 min of treatment.}

The results obtained above were generated from plants treated 15 and $30 \mathrm{~min}$ after chitooctaose treatment. In order to extend these observations and to confirm the results, independent qRTPCR experiments were performed, using Arabidopsis plants treated with chitooctaose for 60,90 , or $120 \mathrm{~min}$. Analyses were performed on $41 \mathrm{TF}$ genes, selected from the list of 118 genes according to their fold change and their family membership (Supplemental Table III). According to the National Center for Biotechnology Information (NCBI) database, two to three transcript variants exist for four of these 41 genes (AT4G31550 (WRKY11), AT2G23320 (WRKY15), AT5G59780 (MYB59), and AT3G54810 (C2C2(Zn) GATA transcription factor). Therefore, when possible, primers were designed that would distinguish between the various transcripts. All the primers were compared against the NCBI database to check their specificity.

Respectively, 39 and two TF genes were found significantly up- and down-regulated, respectively, by chitooctaose treatment at one or more of the five timepoints tested (Fig. 2; Supplemental Table IV). The results clearly show the maximum response to chitooctaose occurs 30 and $60 \mathrm{~min}$ after chitin treatment and less often after $15 \mathrm{~min}$ of chitin treatment (Fig. 2 ). These data are consistent with previous results (Ramonell et al. 2005).

\section{Expression \\ of the AP2/ERE, MYB, WRKY, and GRAS gene families.}

As mentioned above, four gene families were overrepresented among the chitooctaose-responsive TF genes (i.e., AP2/ERE, C2H2 zinc finger, MYB, and WRKY families). We focused on selected members of AP2/ERE, MYB, and WRKY families to better characterize their response during the first 2 $\mathrm{h}$ of chitooctaose elicitation. In addition, because rice GRAS family members were implicated in the response to chitin (Day et al. 2003), we also selected a few Arabidopsis GRAS genes for this analysis. Specifically, we selected seven (AT1G22810, AT1G64380, AT3G23230, AT5G51190, AT4G17490, AT5G47230, AT5G61590) from the AP2/ERE family, two 
(AT1G18570, AT5G59780) from MYB, six (AT2G23320, AT2G46400, AT4G23810, AT4G31550, AT5G15130, $A T 2 G 38470)$ from WRKY, and four (AT1G07520, AT3G46600, AT4G17230, AT5G59450) from the GRAS family (Fig. 2).

The members of the AP2/ERE and MYB TF family were upregulated 2.2- (AT5G47230, $60 \mathrm{~min}$ ) to 171-fold (AT3G23230, $60 \mathrm{~min}$ ) and 19-fold (AT1G18570, $60 \mathrm{~min})$, respectively. Some genes were down-regulated. For example, members of the AP2/ ERE and MYB families were repressed 2.2- (AT5G61590, 30 $\mathrm{min}$ ) and 4.8-fold (AT5G59780, $30 \mathrm{~min}$ ).

The selected members of the GRAS and WRKY TF families were exclusively up-regulated after chitin treatment (the maximum response for each gene was, respectively, between 3.6[AT1G07520, $60 \mathrm{~min}]$ to 4.7 -fold [AT4G17230, $60 \mathrm{~min}]$ and

Table 1. The expression of 118 Arabidopsis transcription factor (TF) genes respond to chitooctaose treatment ${ }^{\mathrm{a}}$

\begin{tabular}{|c|c|c|c|c|c|}
\hline \multirow[b]{2}{*}{ Gene family } & \multirow[b]{2}{*}{ Gene ID } & \multicolumn{2}{|c|}{ Response after 15 min } & \multicolumn{2}{|c|}{ Response after $30 \mathrm{~min}$} \\
\hline & & $t$ Test & Fold Change & $t$ Test & Fold Change \\
\hline \multicolumn{6}{|c|}{ TF genes identified by high-throughput qPCR reaction } \\
\hline \multirow{23}{*}{$\mathrm{AP} 2 / \mathrm{ERE}$} & AT1G21910 & 0.00091 & 2.1 & & \\
\hline & AT1G22810 & 0.00430 & 39.2 & 0.00293 & 91.9 \\
\hline & AT1G28370 & 0.00035 & 3.9 & 0.00822 & 6.7 \\
\hline & AT1G33760 & 0.00436 & 3.9 & 0.00063 & 7.4 \\
\hline & AT1G53170 & & & 0.04880 & 2.1 \\
\hline & AT1G64380 & 0.00279 & 3.5 & & \\
\hline & AT1G68840 & 0.00994 & 3.1 & 0.00728 & 3.0 \\
\hline & AT1G71520 & & & 0.03147 & 101.6 \\
\hline & AT1G75490 & 0.00710 & 2.3 & & \\
\hline & AT1G77640 & & & 0.04020 & 2.4 \\
\hline & AT2G31230 & & & 0.00084 & 3.8 \\
\hline & AT2G33710 & 0.03310 & 5.9 & 0.00005 & 18.2 \\
\hline & AT2G44840 & 0.00671 & 17.1 & 0.00038 & 37.5 \\
\hline & AT3G15210 & 0.00401 & 2.6 & 0.02988 & 2.7 \\
\hline & AT3G23250 & & & 0.01389 & 9.1 \\
\hline & AT3G50260 & & & 0.00020 & 3.4 \\
\hline & AT4G17500 & 0.01168 & 3.6 & 0.00200 & 4.4 \\
\hline & AT4G18450 & 0.00942 & 3.6 & 0.00006 & 4.3 \\
\hline & AT4G28140 & & & 0.01630 & 3.7 \\
\hline & AT4G34410 & 0.00000 & 4.3 & 0.00165 & 5.7 \\
\hline & AT5G47220 & 0.02225 & 2.8 & 0.00265 & 3.9 \\
\hline & AT5G61590 & & & 0.00711 & 0.5 \\
\hline & AT5G61600 & 0.00557 & 9.5 & 0.00554 & 8.3 \\
\hline ARR-A class transcription factor & AT1G19050 & & & 0.01684 & 2.3 \\
\hline Aux/IAA & AT1G04100 & & & 0.03550 & 2.5 \\
\hline \multirow[t]{3}{*}{ bHLH,Basic Helix-Loop-Helix } & AT1G32640 & & & 0.00792 & 2.6 \\
\hline & AT3G56770 & 0.01772 & 2.1 & & \\
\hline & AT5G56960 & & & 0.01048 & 15.6 \\
\hline \multirow[t]{4}{*}{ bZIP transcription factor } & AT2G34600 & 0.02466 & 7.9 & & \\
\hline & AT2G36270 & & & 0.04707 & 2.1 \\
\hline & AT4G29110 & & & 0.01886 & 3.2 \\
\hline & AT2G17770 & & & 0.00736 & 16.8 \\
\hline \multirow[t]{2}{*}{$\mathrm{C} 2 \mathrm{C} 2(\mathrm{Zn}) \mathrm{CO}$-like, Constans-like zinc finger } & AT3G21150 & 0.01040 & 3.2 & 0.00320 & 14.6 \\
\hline & AT4G39070 & & & 0.00769 & 2.2 \\
\hline $\mathrm{C} 2 \mathrm{C} 2(\mathrm{Zn}) \mathrm{DOF}$ zinc finger & AT1G51700 & 0.00028 & 4.6 & 0.00229 & 14.3 \\
\hline \multirow[t]{13}{*}{$\mathrm{C} 2 \mathrm{H} 2$ zinc finger } & AT1G08930 & & & 0.00159 & 3.7 \\
\hline & AT1G27730 & 0.00012 & 10.5 & 0.00024 & 17.2 \\
\hline & AT1G68360 & & & 0.02558 & 2.7 \\
\hline & AT2G37430 & 0.00001 & 34.9 & 0.00017 & 78.6 \\
\hline & AT3G19580 & & & 0.00196 & 10.3 \\
\hline & AT3G46080 & & & 0.00697 & 7.4 \\
\hline & AT3G46090 & 0.00011 & 7.4 & 0.00189 & 11.0 \\
\hline & AT3G53600 & & & 0.00790 & 5.3 \\
\hline & AT5G04340 & & & 0.00036 & 11.9 \\
\hline & AT5G22890 & & & 0.01644 & 0.5 \\
\hline & AT5G43170 & 0.01205 & 2.2 & & \\
\hline & AT5G59820 & & & 0.00120 & 13.3 \\
\hline & AT5G67450 & 0.00113 & 6.3 & 0.00119 & 17.1 \\
\hline $\mathrm{C} 3 \mathrm{H}$ zinc finger & AT3G55980 & 0.00007 & 9.7 & 0.00003 & 14.0 \\
\hline CHP-rich & AT4G01350 & & & 0.01438 & 2.6 \\
\hline expressed protein & AT5G13220 & & & 0.01943 & 3.1 \\
\hline F-box protein & AT1G09650 & 0.01684 & 0.4 & & \\
\hline \multirow[t]{3}{*}{ GRAS transcription factor } & AT1G07520 & & & 0.01073 & 3.4 \\
\hline & AT3G46600 & 0.00310 & 2.2 & 0.02495 & 3.3 \\
\hline & AT5G59450 & & & 0.04996 & 3.5 \\
\hline HB,Homeobox transcription factor & AT3G49530 & 0.00010 & 2.3 & 0.00529 & 3.7 \\
\hline \multirow[t]{4}{*}{ HSF,Heat-shock transcription factor } & AT1G67970 & 0.04882 & 2.1 & 0.02356 & 2.6 \\
\hline & AT2G26150 & & & 0.01421 & 2.2 \\
\hline & AT4G18880 & 0.01236 & 3.3 & 0.00154 & 9.0 \\
\hline & & & & \multicolumn{2}{|c|}{ Continued on next page } \\
\hline
\end{tabular}

\footnotetext{
${ }^{a} P$ values associated with these experiments. Down-regulated genes are highlighted by showing values in bold italics, others are all up-regulated. The genes
} are grouped by gene family. Fold change shown is the average. 
8.1- [AT2G23320, $60 \mathrm{~min}]$ to 31.3-fold [AT4G23810, $60 \mathrm{~min}]$ ). Together with the results obtained from the primer library, we identified 14 WRKY genes that were significantly up-regulated 15 to 120 min after chitin treatment. To complete the analysis of the WRKY TF family, we compared the expression levels of the three transcript variants encoded by AT4G31550 (WRKY11). At 15 min after chitooctaose treatment, AT4G31550.3 was upregulated more than transcript variant AT4G31550.1 and
AT4G31550.2 (Fig. 2). At later timepoints, this difference was less noticeable (Fig. 2).

\section{Expression of 30 putative ubiquitin-ligase genes is affected} by chitooctaose treatment.

The ubiquitin-ligase genes are also known to play a role in the plant defense response (Liu et al. 2002; Yang et al. 2006). Therefore, predicted members of this family were also analyzed by

Table 1. Coninued from preceding page

\begin{tabular}{|c|c|c|c|c|c|}
\hline \multirow[b]{2}{*}{ Gene family } & \multirow[b]{2}{*}{ Gene ID } & \multicolumn{2}{|c|}{ Response after $15 \mathrm{~min}$} & \multicolumn{2}{|c|}{ Response after $30 \mathrm{~min}$} \\
\hline & & $t$ Test & Fold Change & $t$ Test & Fold Change \\
\hline \multicolumn{6}{|c|}{ TF genes identified by high-throughput qPCR reaction (continued) } \\
\hline \multicolumn{6}{|c|}{ HSF,Heat-shock transcription factor (continued) } \\
\hline & AT5G03720 & & & 0.00029 & 3.5 \\
\hline & AT5G62020 & 0.00010 & 2.8 & 0.00008 & 5.4 \\
\hline \multirow[t]{2}{*}{ JUMONJI } & AT1G30810 & & & 0.02862 & 2.1 \\
\hline & AT5G46910 & & & 0.01840 & 2.4 \\
\hline \multirow[t]{10}{*}{ MYB domain transcription factor } & AT1G18570 & 0.00112 & 3.2 & 0.00185 & 5.6 \\
\hline & AT1G74650 & & & 0.00034 & 2.7 \\
\hline & AT3G50060 & & & 0.00116 & 3.3 \\
\hline & AT3G53200 & & & 0.01232 & 0.4 \\
\hline & AT4G28110 & 0.02977 & 11.8 & & \\
\hline & AT4G37260 & 0.02652 & 14.1 & 0.00308 & 2.8 \\
\hline & AT5G23000 & & & 0.00046 & 3.0 \\
\hline & AT5G62470 & & & 0.00038 & 8.9 \\
\hline & AT5G67300 & & & 0.00362 & 2.0 \\
\hline & AT5G04760 & & & 0.00962 & 2.8 \\
\hline \multirow[t]{6}{*}{ NAC domain transcription factor } & AT1G34180 & & & 0.00079 & 2.4 \\
\hline & AT3G44350 & & & 0.00033 & 7.7 \\
\hline & AT2G17040 & 0.00135 & 3.7 & 0.00105 & 11.1 \\
\hline & AT2G18060 & 0.03570 & 2.0 & & \\
\hline & AT5G08790 & & & 0.00166 & 2.5 \\
\hline & AT5G24590 & 0.02142 & 2.1 & 0.01225 & 3.3 \\
\hline \multirow[t]{2}{*}{ NPR1-like } & AT4G26120 & & & 0.02216 & 3.0 \\
\hline & AT5G45110 & 0.00907 & 2.8 & 0.02707 & 2.6 \\
\hline Others, DEAD/DEAH box helicase & AT1G19180 & & & 0.00694 & 4.2 \\
\hline PHD finger transcription factor & AT5G58610 & 0.01869 & 2.7 & & \\
\hline Psudo ARR transcription factor & AT5G02810 & 0.02105 & 0.5 & & \\
\hline SET-domain transcriptional regulator & AT2G35160 & & & 0.04507 & 2.2 \\
\hline Trihelix, Triple-Helix transcription factor & AT5G03680 & & & 0.02503 & 0.4 \\
\hline \multirow[t]{3}{*}{ WHIRLY } & AT2G13790 & & & 0.00370 & 3.3 \\
\hline & AT4G33050 & 0.00499 & 2.0 & 0.00187 & 4.8 \\
\hline & AT5G35735 & & & 0.00062 & 4.6 \\
\hline \multirow[t]{10}{*}{ WRKY domain transcription factor } & AT1G62300 & 0.01033 & 2.2 & 0.00135 & 4.1 \\
\hline & AT1G80840 & 0.00031 & 5.7 & 0.00462 & 21.9 \\
\hline & AT2G24570 & & & 0.02464 & 4.4 \\
\hline & AT2G38470 & 0.02319 & 5.5 & & \\
\hline & AT3G56400 & 0.01673 & 2.8 & 0.02684 & 3.7 \\
\hline & AT4G01250 & 0.02327 & 2.3 & 0.01359 & 10.8 \\
\hline & AT4G23550 & & & 0.00494 & 2.7 \\
\hline & AT4G23810 & 0.00442 & 13.0 & 0.00897 & 28.8 \\
\hline & AT4G31800 & 0.00303 & 2.9 & 0.00014 & 5.7 \\
\hline & AT5G49520 & 0.02143 & 2.1 & 0.02704 & 5.6 \\
\hline \multicolumn{6}{|c|}{ TF genes identified by Affymetrix hybridization and confirmed by qRT-PCR } \\
\hline \multirow[t]{4}{*}{$\mathrm{AP} 2 / \mathrm{ERE}$} & AT3G23230 & & & 0.0006 & 57.1 \\
\hline & AT5G51190 & 0.0005 & 21.3 & 0.0002 & 17.8 \\
\hline & AT5G47230 & & & 0.0374 & 2.5 \\
\hline & AT4G17490 & 0.0001 & 14.0 & 0.0006 & 17.9 \\
\hline Argonaute & AT1G31290 & 0.0450 & 6.0 & 0.0068 & 7.1 \\
\hline bZIP transcription factor & AT1G42990 & 0.0004 & 2.5 & 0.0026 & 5.5 \\
\hline $\mathrm{C} 2 \mathrm{C} 2(\mathrm{Zn}) \mathrm{GATA}$ transcription factor & AT3G54810 & & & 0.0164 & 3.1 \\
\hline $\mathrm{C} 2 \mathrm{H} 2$ zinc finger & AT3G28210 & & & 0.0030 & 2.2 \\
\hline & AT3G52800 & 0.0001 & 2.3 & 0.0004 & 3.3 \\
\hline $\mathrm{C} 3 \mathrm{H}$ zinc finger & AT2G40140 & 0.0024 & 6.4 & 0.0007 & 9.0 \\
\hline expressed protein & AT1G17380 & & & 0.0076 & 6.7 \\
\hline GRAS transcription factor & AT4G17230 & 0.0020 & 2.4 & 0.0012 & 4.5 \\
\hline HSF,Heat-shock transcription factor & AT4G11660 & 0.0044 & 2.7 & 0.0149 & 2.5 \\
\hline MYB domain transcription factor & AT5G59780 & & & 0.0089 & 0.2 \\
\hline Transcriptional Adaptor Zinc Bundle (TAZ) domain & AT4G37610 & & & 0.0045 & 2.5 \\
\hline WRKY domain transcription factor & AT4G31550 & 0.0001 & 4.3 & 0.0004 & 10.0 \\
\hline & AT2G23320 & 0.0010 & 2.0 & 0.0066 & 3.7 \\
\hline & AT2G46400 & 0.0000 & 6.3 & 0.0001 & 10.9 \\
\hline & AT5G15130 & 0.0006 & 4.3 & 0.0002 & 6.4 \\
\hline
\end{tabular}


qRT-PCR and by Affymetrix array hybridization starting with the same RNA used for TF gene transcriptional profiling. A total of 30 ubiquitin-ligase genes were found up- or down-regulated at either 15 or 30 min or both after chitooctaose treatment using both methods.

The high-throughput qPCR primer set library allowed us to measure the expression of 150 ubiquitin-ligase genes (Supplemental Table V). These experiments identified five and seven ubiquitin-ligase genes that were significantly up-regulated $(P$ value $<0.05$ and fold change $<0.5$ or $>2$ ) 15 and $30 \mathrm{~min}$, respectively, after chitooctaose treatment (Table 2). None of the ubiquitin-ligase genes were found down-regulated. Four ubiquitin-ligase genes were up-regulated both 15 and $30 \mathrm{~min}$ after chitooctaose treatment. Collectively, qRT-PCR analysis identified a total of eight ubiquitin-ligase genes that were significantly up-regulated 15 and $30 \mathrm{~min}$ after chitooctaose treatment

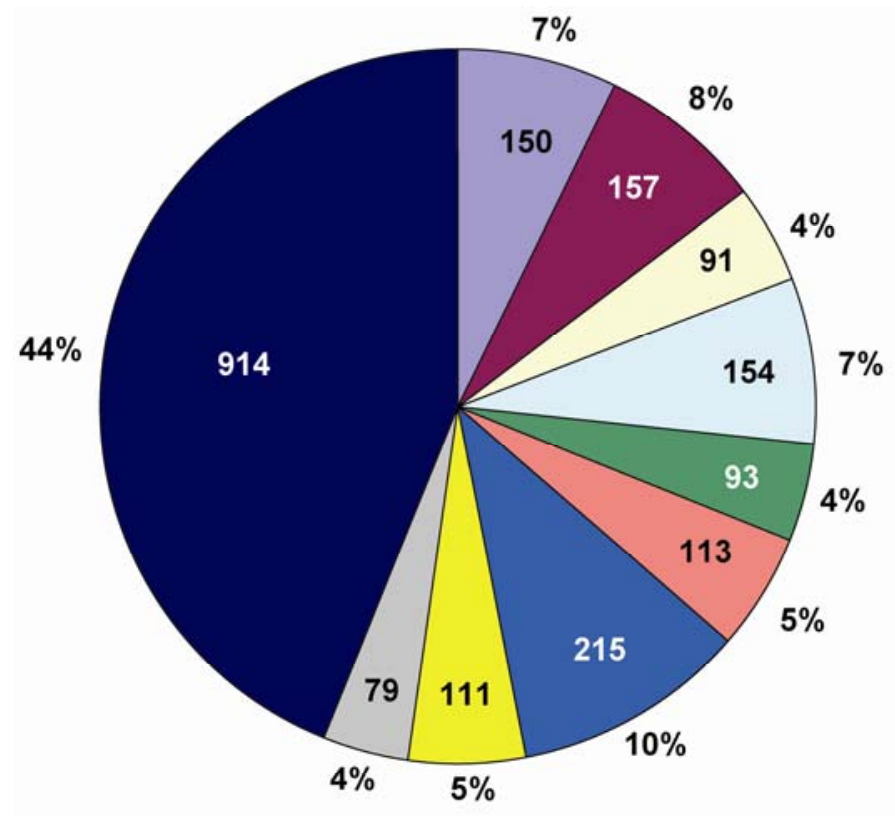

\section{AP2/ERE}

Basic helix-loop-helix

\section{bZIP transcription factor}

\section{$\mathrm{C} 2 \mathrm{H} 2$ zinc finger}

Homeobox transcription factor

MADS transcription factor

MYB domain transcription factor

NAC domain transcription factor

WRKY transcription factor

Other TF families
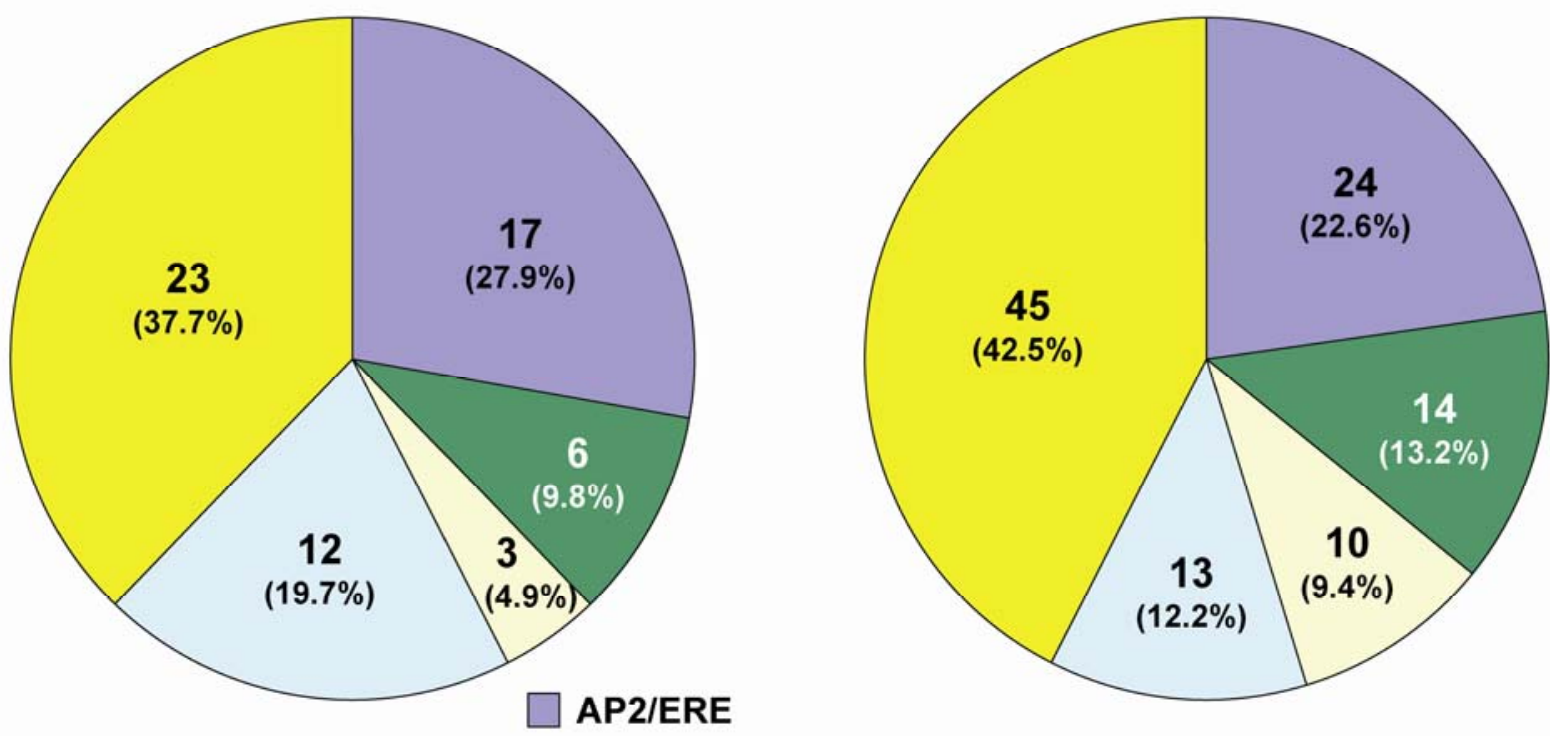

$\mathrm{C} 2 \mathrm{H} 2$ zinc finger

MYB domain transcription factor

WRKY domain transcription factor

\section{Other deregulated TF genes}

Fig. 1. Transcription factor (TF) genes whose expression responded to chitooctaose treatment as determined by high-throughput quantitative reverse transcriptionpolymerase chain reaction (qRT-PCR) analysis. Top, Gene family distribution in the primer set library used for high-throughput TF gene expression analysis by qRT-PCR (we consider this library as including all the Arabidopsis TF genes). The 2,146 primer set allowed the expression analysis by RT-PCR of 2,077 Arabidopsis genes. These genes can be divided into 75 different families. This chart shows the distribution of the most abundant families represented in the number of genes in each family. Bottom left, gene families most responsive after 15 min of treatment and bottom right, those most responsive after 30 min of treatment. The number of genes responding significantly for each family is indicated. The percentage is calculated according to the total number of genes found to be responding significantly (118) and is not based on the total genes analyzed only by qRT-PCR or by Affymetrix DNA microarray hybridization. 
(AT1G74410, AT4G30370, AT5G38895, AT5G66070, AT1G23030, AT1G66160, AT3G52450, and AT5G64660) (Table 2).

Analysis of the Affymetrix array data identified 26 ubiquitinligase genes that were chitooctaose responsive $(P$ value $<0.05$,
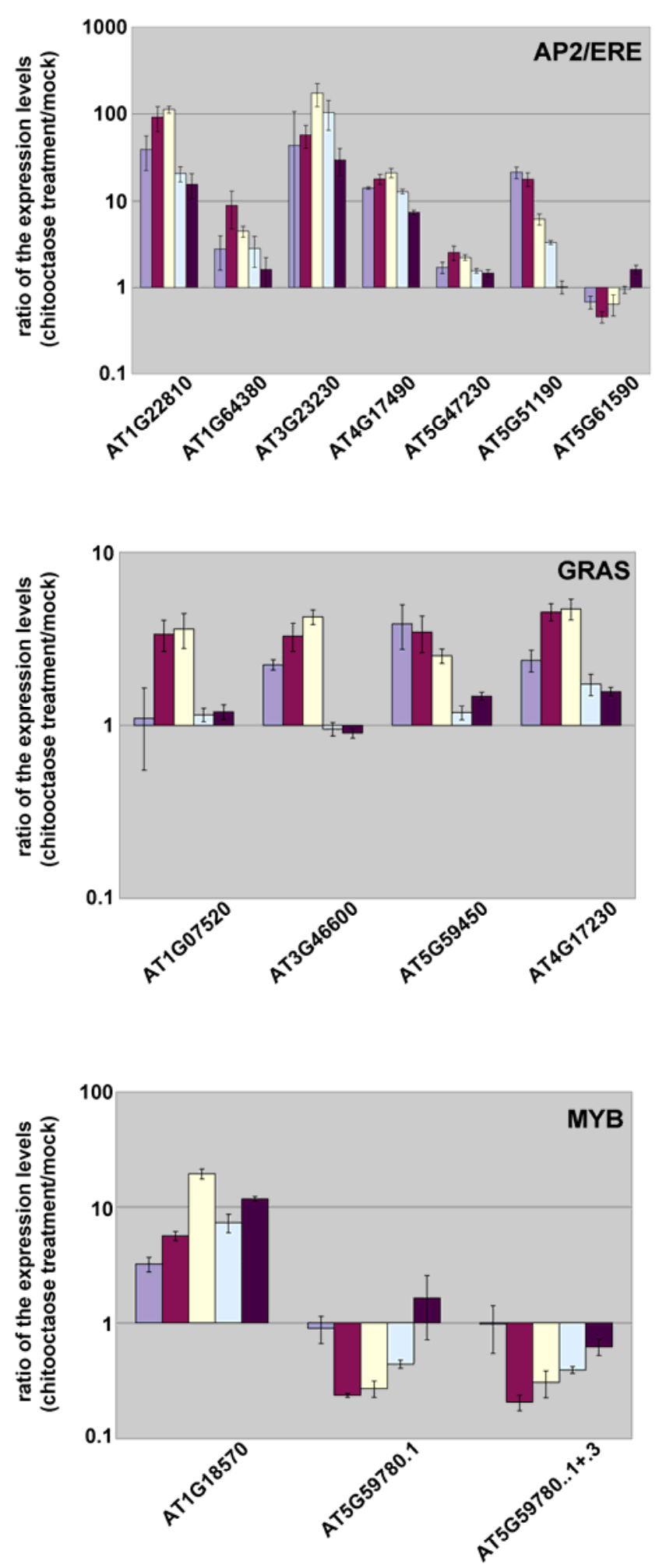

fold change $>2$ or $<0.5$; two were down-regulated and 24 were up-regulated after chitin treatment). However, the expression of only 16 of these 26 genes could be confirmed using the initial qRT-PCR primer set (Czechowski et al. 2004). The qRT-PCR primers for the remaining 10 genes were redesigned and were
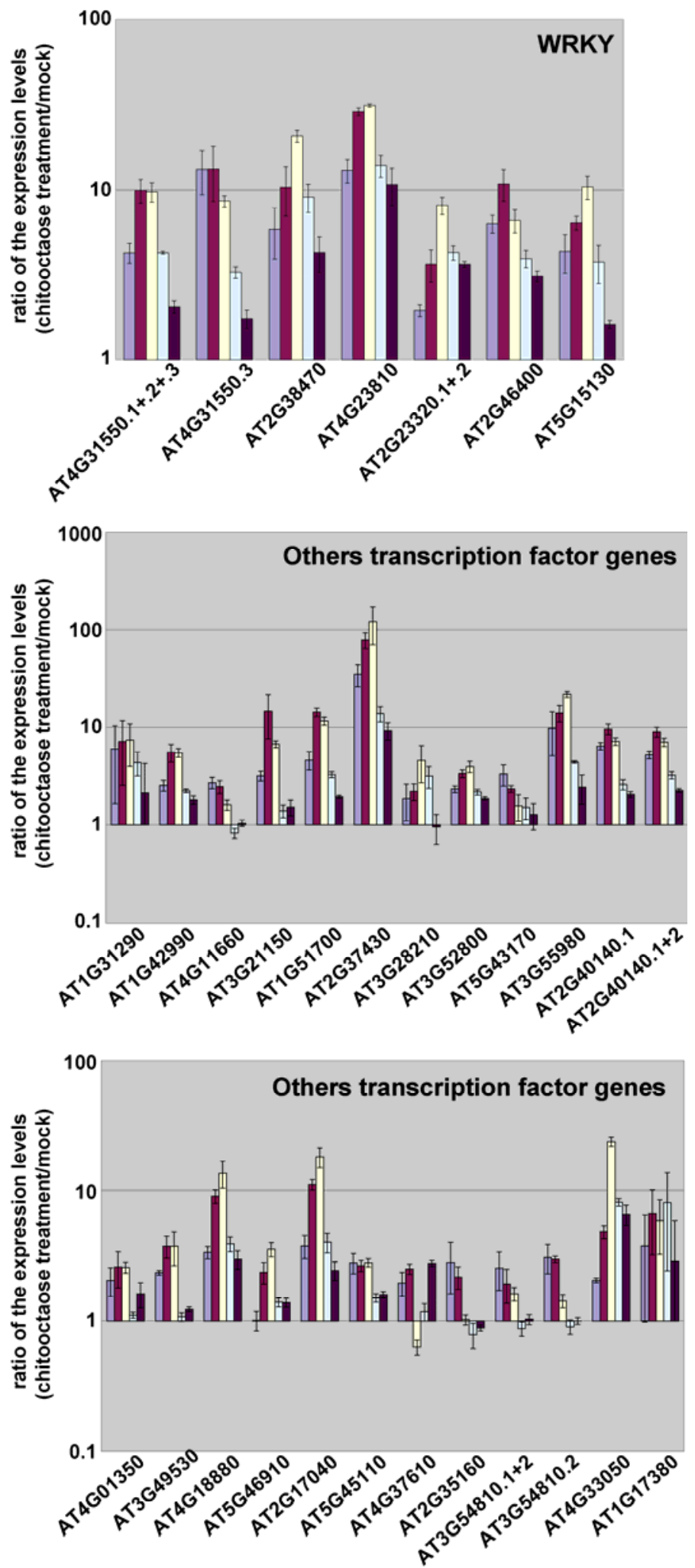

Fig. 2. Analysis of the expression levels of 41 Arabidopsis thaliana transcription factor (TF) genes after chitooctaose treatment. A subset of the TF genes found to respond to chitooctaose by high-throughput quantitative reverse transcription-polymerase chain reaction (qRT-PCR) analysis and microarray hybridization were selected for this study. Using a 96-well format, qRT-PCR reactions were performed on cDNA isolated from plants treated with chitooctaose (left to right) 15 (blue), 30 (purple), 60 (yellow), 90 (blue light), and 120 (dark purple) min. The gene designations are shown on the $x$ axis while the $y$ axis presents the ratio of the expression levels (chitooctaose treatment/mock). 
used to test for expression in response to chitin elicitation. Overall, we were only able to confirm the response of 22 of the 26 genes identified by microarray analysis using qRT-PCR (one down-regulated and 21 up-regulated) (Table 2). Collectively, the qRT-PCR data and Affymetrix data identified 30 ubiquitin-ligase genes that responded to chitooctaose elicitation.

To analyze the expression kinetics of selected ubiquitinligase genes, qRT-PCR experiments were performed on 11 ubiquitin-ligase genes using Arabidopsis plants treated with chitooctaose during 15, 30, 60, 90, and $120 \mathrm{~min}$. Two of the 11 genes analyzed by qRT-PCR (AT2G04240 and AT5G48655) encode different transcript variants. When possible, primers were designed to amplify specifically one transcript variant. Respectively, 10 and 1 ubiquitin-ligase genes were found significantly up- and down-regulated by chitooctaose treatment at one or more of the five timepoints tested (Fig. 3). Similarly to the response of the TF genes to chitin treatment, ubiquitinligase genes are the most regulated by chitooctaose after 30 and 60 min of treatment (Fig. 3).

qPCR analysis revealed that transcript variant AT5G48655.3 was strongly up-regulated at the different timepoints (Fig. 3). Concerning AT2G04240, the transcript variant AT2G04240.2 was down-regulated 15 and $30 \mathrm{~min}$ after chitin treatment, in

Table 2. The expression of 30 ubiquitin-ligase genes respond to chitooctaose treatment $^{\mathrm{a}}$

\begin{tabular}{|c|c|c|c|c|}
\hline \multirow[b]{2}{*}{ Gene ID } & \multicolumn{2}{|c|}{$15 \min$} & \multicolumn{2}{|c|}{$30 \mathrm{~min}$} \\
\hline & $t$ Test & Fold Change & $t$ Test & Fold Change \\
\hline \multicolumn{5}{|c|}{ Genes identified by high-throughput qPCR reaction } \\
\hline AT1G23030 & 0.0141 & 2.0 & & \\
\hline AT1G66160 & 0.0014 & 7.4 & 0.0037 & 4.5 \\
\hline AT1G74410 & & & 0.0487 & 2.4 \\
\hline AT3G52450 & 0.0075 & 7.3 & 0.0186 & 9.6 \\
\hline AT4G30370 & 0.0307 & 3.0 & 0.0279 & 3.9 \\
\hline AT5G38895 & & & 0.0307 & 2.8 \\
\hline AT5G64660 & & & 0.0005 & 6.2 \\
\hline AT5G66070 & 0.0076 & 3.6 & 0.0008 & 5.1 \\
\hline \multicolumn{5}{|c|}{ Genes identified Affymetrix hybridization and confirmed by qRT-PCR } \\
\hline AT1G20823 & $\ldots$ & $\ldots$ & 0.0119 & 10.8 \\
\hline AT2G04240.1+2 & $\ldots$ & $\ldots$ & 0.0115 & 0.6 \\
\hline AT2G04240.2 & $\ldots$ & $\ldots$ & 0.0130 & 0.3 \\
\hline AT2G28830 & $\ldots$ & $\ldots$ & 0.0014 & 2.6 \\
\hline AT2G35930 & $\ldots$ & $\cdots$ & 0.0141 & 10.2 \\
\hline AT3G05200 & $\ldots$ & $\ldots$ & 0.0323 & 4.6 \\
\hline AT3G11840 & $\ldots$ & $\ldots$ & 0.0007 & 19.0 \\
\hline AT3G16720 & $\ldots$ & $\ldots$ & 0.0116 & 8.9 \\
\hline AT3G18710 & $\ldots$ & $\ldots$ & 0.0001 & 11.0 \\
\hline AT3G19380 & $\ldots$ & $\ldots$ & 0.0173 & 2.1 \\
\hline AT3G46620 & $\ldots$ & $\ldots$ & 0.0051 & 7.9 \\
\hline AT4G11360 & $\ldots$ & $\ldots$ & 0.0119 & 3.3 \\
\hline AT4G15975 & $\ldots$ & $\ldots$ & 0.0065 & 25.4 \\
\hline AT4G26400 & $\ldots$ & $\ldots$ & 0.0175 & 3.9 \\
\hline AT4G33940 & $\ldots$ & $\ldots$ & 0.0023 & 2.4 \\
\hline AT4G35480 & $\ldots$ & $\ldots$ & 0.0234 & 8.0 \\
\hline AT5G01830 & $\ldots$ & $\ldots$ & 0.0142 & 4.7 \\
\hline AT5G09800 & $\ldots$ & $\ldots$ & 0.0053 & 5.8 \\
\hline AT5G10380 & $\ldots$ & $\cdots$ & 0.0409 & 2.1 \\
\hline AT5G27420 & $\ldots$ & $\ldots$ & 0.0028 & 26.7 \\
\hline AT5G37490 & $\ldots$ & $\ldots$ & 0.0011 & 18.0 \\
\hline AT5G48655.1+.2+. 3 & $\ldots$ & $\ldots$ & 0.2506 & 2.8 \\
\hline AT5G48655.3 & $\ldots$ & $\ldots$ & 0.0000 & 19.6 \\
\hline AT5G59550 & $\ldots$ & $\ldots$ & 0.0008 & 9.0 \\
\hline
\end{tabular}

${ }^{a}$ The average ratio of chitooctaose/mock treatment between three independent replicates is shown for each of the ubiquitin-ligase genes identified by high-throughput quantititative polymerase chain reaction (PCR) reaction (15 and $30 \mathrm{~min}$ ) and by Affymetrix hybridization and confirmed by quantitative reverse transcription-PCR (30 min). Also shown are the $P$ values associated with these experiments. Down-regulated genes are highlighted by showing values in bold italics, others are all up-regulated. comparison to $A T 2 G 04240.1$ (Fig. 3). Interestingly, for each of these genes, the expression level of one transcript variant was more affected by chitin than the others, especially $30 \mathrm{~min}$ after treatment (AT5G48655.3, AT2G04240.2) (Fig. 3).

\section{Comparison}

of qRT-PCR reactions and Affymetrix Array results.

As discussed above, using the same RNA samples (30 min after chitooctaose treatment), high-throughput qRT-PCR and Affymetrix analysis of transcript abundance gave significantly different results for selected genes.

The Affymetrix Arabidopsis whole-genome array (ATH1) represents approximately 24,000 genes with 1,912 putative TF and ubiquitin-ligase genes represented. Using the DNA microarray analysis software DNA Chip Analyzer (dChip) (Li and Wong 2001a and b), 90 of the 1,912 TF and ubiquitin-ligase genes $(4.7 \%)$ were found to be significantly responsive $30 \mathrm{~min}$ after chitin treatment (twofold, $P$ value $<0.05$ ). By comparison, among the 94 (4.2\% of the 2,227) genes found responsive to chitin by high-throughput qPCR at this timepoint, 85 genes are found on the Affymetrix array. A comparison of the microarray and qRT-PCR results showed that 52 of the 85 genes $(61.2 \%)$ analyzed both by qRT-PCR and DNA microarray were confirmed by both methods. Totals of 33 and 38 genes, respectively, were identified either only by qRT-PCR or only by the Affymetrix arrays.

Because more than $50 \%$ of the $\mathrm{TF}$ and ubiquitin-ligase genes were found by both methods to be regulated by chitooctaose, qPCR and microarray hybridization are valuable complementary technologies to detect gene expression. However, what about those genes identified by only one of these methods? The average microarray spot intensity for those genes identified only by qRT-PCR was 341 . In contrast, the average spot intensity for those genes found regulated by chitooctaose after microarray hybridization was 787. Therefore, the lack of detection of specific genes by the microarray is likely due to an inability to accurately measure the expression of low-abundance mRNA, as compared with qPCR. These results confirm the usefulness of qRT-PCR for exploring the expression of low-expressed genes.

On the other hand, as discussed before, subsequent qRTPCR experiments were able to confirm the regulation by chitooctaose of $19 \mathrm{TF}$ and 10 ubiquitin-ligase genes not identified by our initial high-throughput qPCR reactions. However, this confirmation required redesigning the primers used for qRTPCR. Thus, use of the correct primer sequences was the crucial parameter to analyze the expression of these 29 genes.

\section{Plant response to chitin depends on $d . p$.}

Previous studies with a variety of plants showed that the response to chitin was dependent on the $d . p$., with the larger chitin oligomers (d.p. $=7$ to 8 ) being most effective (Day et al. 2001; Wan et al. 2004; Zhang et al. 2002). Therefore, we compared the response of the $41 \mathrm{TF}$ genes and the 11 ubiquitinligase genes to either chitotetraose $(d . p .=4)$ or chitooctaose after $30 \mathrm{~min}$ of treatment. Chitotetraose treatment did not affect the expression of $37 \mathrm{TF}$ and 10 ubiquitin-ligase genes $(P$ value $>0.05$ or fold change $>0.5$ or $<2$ ) (Fig. 4, Supplemental Table VI). However, the expression of four TF genes (AT4G23810, AT4G31550.3, AT2G37430, AT4G17490) and one ubiquitin-ligase gene (AT5G48655.3) responded both to chitotetraose $(P$ value $<0.05$ and fold change $<0.5$ or $>2)$ (Fig. $4)$ and chitooctaose. Interestingly, expression of two transcript variants (AT5G48655.3, AT4G31550.3) was more affected than the others (Fig. 4). Nevertheless the expression of these five genes was less affected by chitotetraose than by chitooctaose treatment. Comparison of the expression level of these 
genes between plants treated 30 min with chitooctaose and chitotetraose suggests that only those genes strongly expressed in response to chitooctaose also responded to chitotetraose. Therefore, it is likely that these results do not reflect a difference in specificity but merely a reflection of the sensitivity of some genes to chitin elicitation.

\section{DISCUSSION}

Chitin reprograms plant gene expression.

Chitin-responsive TF genes likely represent key elements in the ability of chitin to modify gene expression as part of the plant defense reaction. Indeed, previous microarray results showed that a large number of genes were affected more than 1.5 -fold by chitooctaose treatment, with 1,070 genes up-regulated and 550 genes down-regulated (Ramonell et al. 2005). TF gene families previously implicated in the plant defense response are specifically affected by chitin. For example, the expression of $27 \mathrm{AP} 2 / \mathrm{ERE}, 15 \mathrm{C} 2 \mathrm{H} 2$ zinc finger, $11 \mathrm{MYB}, 14$ WRKY, and four GRAS TF genes were affected by chitooctaose. Members from these TF families were previously shown or implicated to modulate plant defense (Eulgem 2005; Eulgem et al. 2000; Gutterson and Reuber 2004). For example, OsEREBP1 (Kim et al. 2000), an Oryza sativa member of the AP2/ERE gene family, and 16 Arabidopsis AP2/ERE genes were reported to respond to fungal inoculation (Alternaria brassicicola; McGrath et al. 2005). Likewise, the expression of five AthC2H2 zinc finger genes (McGrath et al. 2005) responded to Alternaria brassicicola. In Arabidopsis, the expression of AtMYB30 (Vailleau et al. 2002) and 12 other Arabidopsis MYB genes (McGrath et al. 2005) was affected by bacterial pathogens and Alternaria brassicicola, respectively. In tobacco, one MYB gene was down-regulated after insect infestation (Hui et al. 2003), while the AtPAPl gene, which encodes a MYB-like transcription factor, was implicated in the response to armyworm (Spodoptera frugiperda) (Johnson and Dowd 2004). The Nicotiana tabacum MYB gene NtMYB1 has a role in plant resistance against Tobacco mosaic virus (Yang and Liu et al. 2004; Klessig 1996). Furthermore, expression of $15 O$. sativa genes, nine A. thaliana, one Nicotiana attenuata, and one parsley WRKY gene was shown to be affected by fungal inoculation (Eulgem et al. 1999; McGrath et al. 2005; Ryu et al. 2006), insect infestation (Hui et al. 2003), and by chitin in our earlier DNA microarray experiments (Ramonell et al. 2005). Four Arabidopsis WRKY genes (WRKY18, WRKY33, $W R K Y 40$, and WRKY60) were found to be induced by the necrotrophic fungal pathogen Botrytis cinerea (Xu et al. 2006; Zheng et al. 2006). The Arabidopsis WRKY11, WRKY17, $W R K Y 18$, WRKY40, and WRKY60 genes were induced by the bacterium Pseudomonas syringae (Journot-Catalino et al. 2006; Xu et al. 2006). Interestingly, out of these six WRKY genes, we identified five to be induced after 15 to $30 \mathrm{~min}$ of chitooctaose treatments (WRKY33, WRKY11, WRKY17, $W R K Y 18$, and $W R K Y 40$ ). Finally, the expression of two rice $G R A S$ genes was shown to be affected by $N$-acetylchitooligosaccharide treatments (Day et al. 2003, 2004).

Recently, McGrath and associates (2005) also used highthroughput qRT-PCR screens to analyze the response of Arabidopsis to fungal pathogen inoculation (Alternaria brassicicola). A comparison of our results to this published study, reveals $18 \mathrm{TF}$ genes responsive to fungus inoculation and chitin treatment, specifically, $10 \mathrm{AP} 2 / \mathrm{ERE}$ genes, two AthC2H2 zinc finger genes, two MYB genes, and four WRKY genes (Table 3). McGrath and associates (2005) also reported the results for

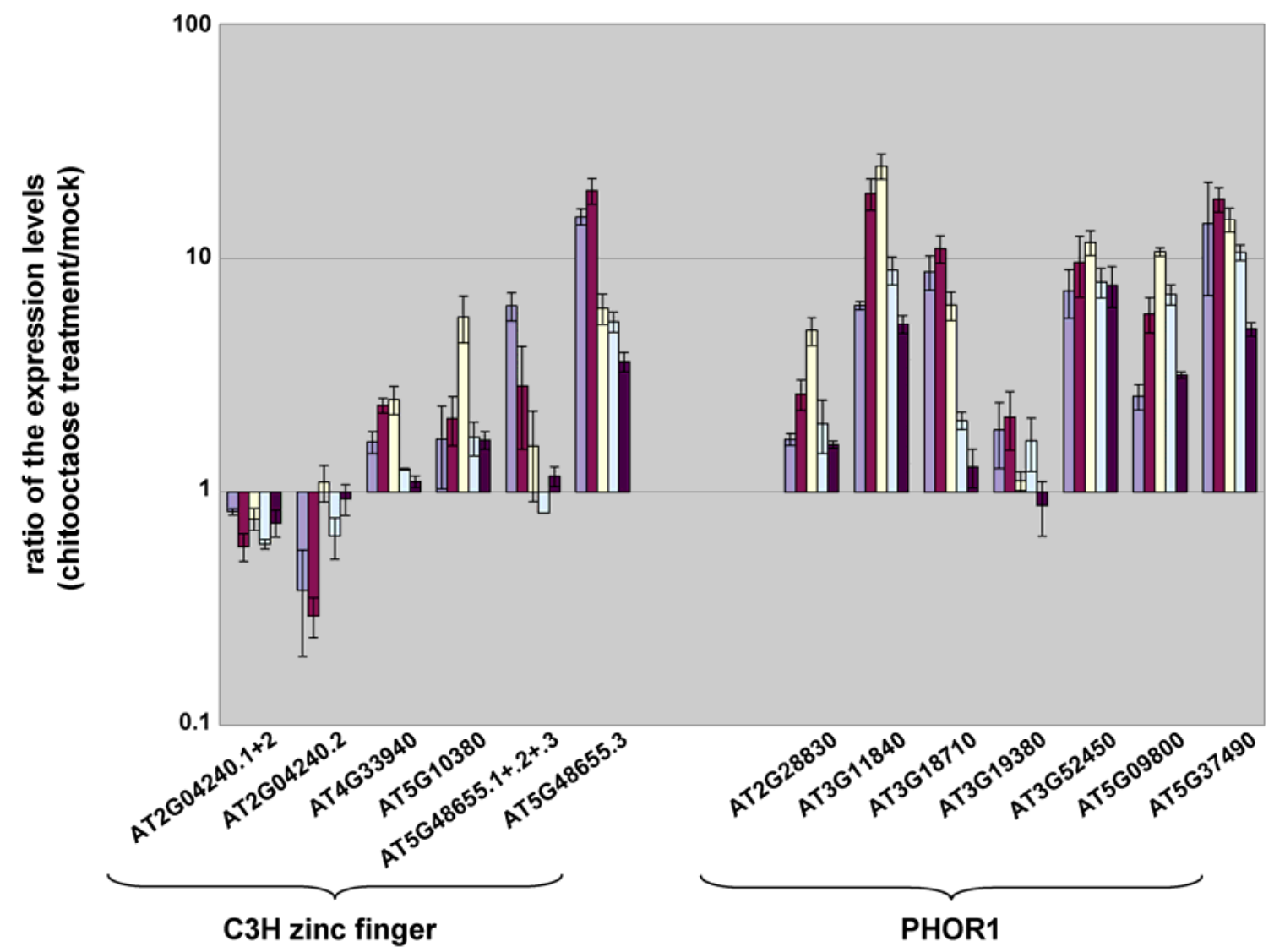

Fig. 3. Analysis of the expression levels of 11 Arabidopsis thaliana ubiquitin-ligase genes after chitooctaose treatment. Quantitative polymerase chain reactions were performed on cDNA isolated from plants treated with chitooctaose (left to right) 15 (blue), 30 (purple), 60 (yellow), 90 (blue light), and 120 (dark purple) min. The gene designations are shown on the $x$ axis, while the $y$ axis presents the ratio of the expression levels (chitooctaose treatment/mock). 
TF gene expression in response to JA treatment. A comparison of these results to those of chitooctaose treatment identifies 15 TF genes (nine AP2/ERE, two AthC2H2 zinc finger, $1 \mathrm{MYB}$, and three WRKY genes) responsive to both treatments (Table 3). Collectively, a total of $20 \mathrm{TF}$ genes were responsive to chi-
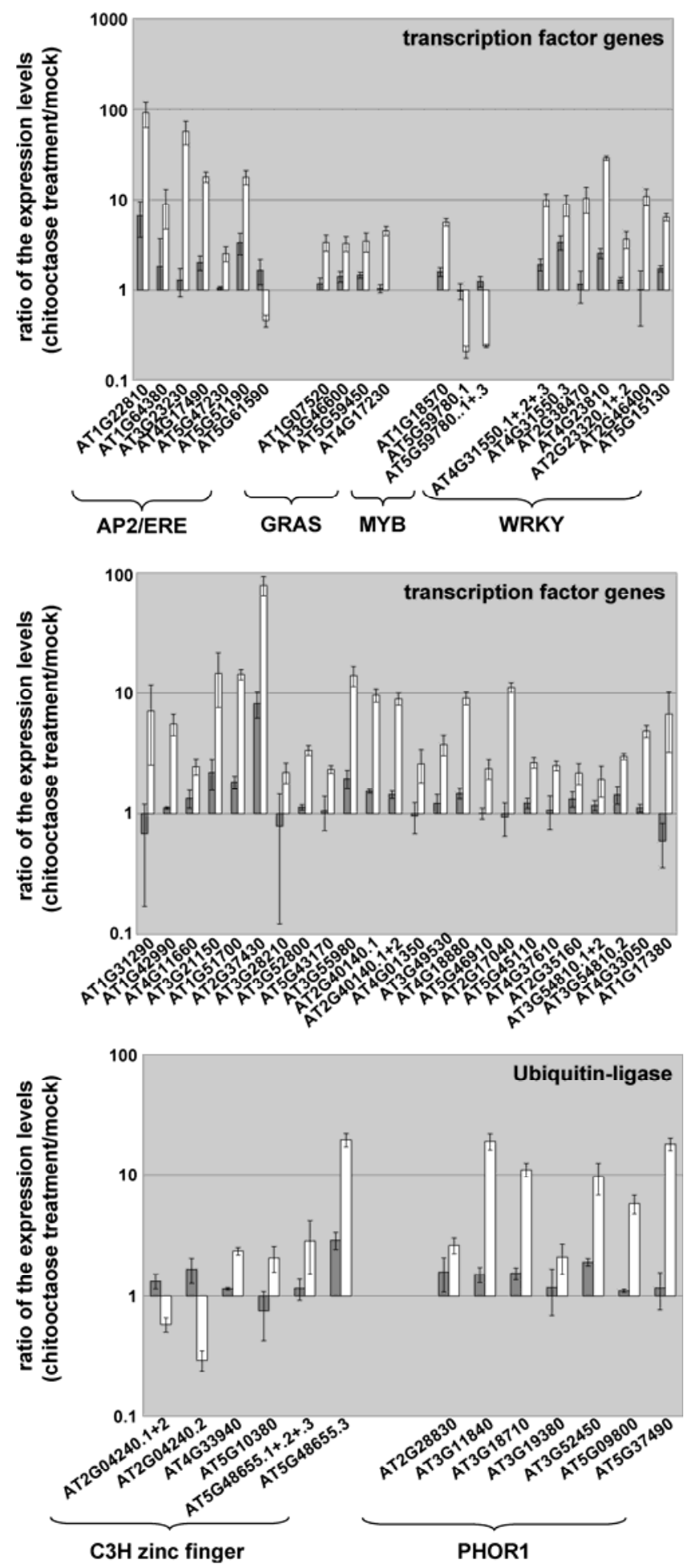

Fig. 4. Comparison of the expression levels of Arabidopsis thaliana ubiquitin-ligase and transcription factor genes after chitotetraose and chitooctaose treatment. Quantitative polymerase chain reactions were performed on cDNA isolated from plants treated $30 \mathrm{~min}$ with chitotetraose (gray) or chitooctaose (white) at a final concentration of $1 \mu \mathrm{M}$. The gene designations are shown on the $x$ axis, while the $y$ axis presents the ratio of the expression levels (chitin treatment/mock). tooctaose and to either JA treatment or fungal inoculation (Table 3). This type of comparison allows the identification of those TF genes most likely to play a crucial role in the integration of plant defense responses to biotic stress.

Flagellin, another PAMP elicitor, was shown to affect the expression of TF genes, specially the WRKY family (Navarro et al. 2004). More precisely, four WRKY genes (AT4G31550, $A T 2 G 38470, A T 4 G 23810$, and AT2G23320) were responsive to both chitooctaose and flagellin flg22. It is the interplay of such factors that likely governs the expression of specific genes.

Thirty ubiquitin-ligase like genes are regulated by chitin.

Our current study identified 30 putative ubiquitin-ligase-like genes whose expression responded to chitooctaose treatment (eight identified from the high-throughput qRT-PCR library and 22 identified by Affymetrix array with subsequent qRTPCR confirmation with redesigned primers). Ubiquitin-ligases are involved in the ubiquitination of a target protein to target it for degradation. Ubiquitin-mediated protein degradation was previously shown to be involved in many developmental events and responses to environmental cues (Vierstra 2003). Increasing evidence also supports a critical role for ubiquitination and protein degradation in plant defense responses (Devoto et al. 2003; Vierstra 2003). The response of these genes to chitin elicitation is consistent with this idea.

\section{Chitin differentially regulates transcript variants of some TF and ubiquitin-ligase genes.}

Among the $118 \mathrm{TF}$ genes and the 30 ubiquitin-ligase genes regulated by chitin, a few exhibit differential splicing resulting in different transcript variants. Chitooctaose treatment differentially affected the expression of transcript variants encoded by the WRKY11 gene (AT4G31550) and two ubiquitin-ligase genes (AT5G48655 and AT2G04240). Such differential responses by transcript variants are commonly observed in defense-related genes, e.g., the tobacco $N$ gene (Dinesh-Kumar and Baker 2000) and Mla genes (Halterman et al. 2003). Recently, Li and associates (2006) discovered that the four tran-

Table 3. List of 20 transcription factor (TF) genes that were responsive to chitooctaose and to fungal or jasmonic acid treatment, or both ${ }^{\mathrm{a}}$

\begin{tabular}{|c|c|c|c|}
\hline Annmotation & Name & $\begin{array}{c}\text { Alternaria } \\
\text { brassicicola }\end{array}$ & MeJA \\
\hline \multicolumn{2}{|c|}{ AP2/ERE gene family } & • & \\
\hline \multicolumn{4}{|c|}{ AT1G22810 } \\
\hline AT1G28370 & \multirow[t]{2}{*}{ ATERF11/ERF11 } & • & • \\
\hline AT1G33760 & & - & • \\
\hline AT1G75490 & & & - \\
\hline AT2G44840 & ATERF13 & • & • \\
\hline AT3G15210 & \multirow[t]{3}{*}{ ATERF-4/ATERF4/ERF4/RAP 2.5} & • & \multirow[t]{2}{*}{$\bullet$} \\
\hline AT3G23250 & & • & \\
\hline AT3G50260 & & & \multirow[t]{2}{*}{ • } \\
\hline AT4G17490 & ATERF6 & • & \\
\hline AT4G17500 & \multirow{2}{*}{ ATERF-1 } & • & - \\
\hline AT3G23230 & & - & - \\
\hline AT5G47220 & ATERF-2/ATERF2/ERF2 & • & - \\
\hline \multicolumn{4}{|c|}{$\mathrm{C} 2 \mathrm{H} 2$ zinc finger gene family } \\
\hline AT1G27730 & \multirow[t]{2}{*}{ ZAT10 } & - & - \\
\hline AT2G37430 & & - & - \\
\hline \multicolumn{4}{|c|}{ MYB domain transcription factor gene family } \\
\hline AT1G18570 & MYB51 & - & \multirow[t]{2}{*}{$\cdot$} \\
\hline AT5G59780 & MYB27 & • & \\
\hline \multicolumn{4}{|c|}{ WRKY domain transcription factor gene family } \\
\hline AT1G80840 & WRKY4O & - & - \\
\hline AT2G38470 & WRKY33 & - & • \\
\hline AT4G23810 & WRKY53 & • & \\
\hline AT4G31800 & WRKY18 & - & • \\
\hline
\end{tabular}

${ }^{a}$ Data from McGrath et al. 2005. • indicates response was present. 
script variants encoded by an Arabidopsis MYB transcription factor gene (AT5G59780, MYB59) were differentially regulated by JA, SA, and ET, plant hormones important in mediating plant defense. The current data are consistent with the fact that cellular signaling involved in the plant defense response differentially affects the splicing of key regulators.

\section{Chitin elicitation depends on $d . p$.}

In general, the expression of the chitin-responsive genes responded specifically to the presence of chitooctaose (with a d.p. of 8) and was not responsive to treatment with chitotetraose (with a d.p. of 4). These results are in agreement with previous findings using Arabidopsis (Wan et al. 2004; Zhang et al. 2002) and a variety of other plant species (Cabrera et al. 2006; Shibuya and Minami 2001; Stacey and Shibuya 1997). However, smaller chitin fragments were shown to specifically activate ERK (extracellular regulated kinase) pathways in embryonic zebrafish cell lines (with a d.p. of 4; Snaar-Jagalska et al. 2003), to induce cortical cell divisions in red clover roots expressing the pea lectin gene (with a d.p. of 2 to 4; Diaz et al. 2000), and to induce extracellular alkalinization and protein phosphorylation in tomato cells (with a d.p. of 1 to 5; Felix et al. 1993, 1998). Therefore, further investigation may be warranted to explore whether plants possess pathways that respond to lower molecular weight chitin oligomers.

\section{Real-time qPCR vs. DNA microarray.}

Czechowski and associates (2004) in their original description of the use of qRT-PCR to screen the expression levels of Arabidopsis TF genes pointed to the $>100$-fold sensitivity of this method in comparison to DNA microarray hybridization. In the current study, we directly compared these two methods. Our results support the fact that the qRT-PCR method is more sensitive as evidenced by the identification of 33 additional chitin-responsive TF genes missed by DNA microarray analysis. However, there were also chitin-responsive genes that were found by DNA microarray hybridization that were missed in the high-throughput qRT-PCR screen. Some of these genes could be confirmed by qRT-PCR, using redesigned primers. Others may also reflect true expression and were simply missed by qRT-PCR due to suboptimal PCR primer design. Therefore, our results indicate that high-throughput qRT-PCR and DNA microarray hybridization methods are complementary approaches that, when used together, reveal the most complete picture of gene expression. These results also urge caution in blindly using qRT-PCR results with a single primer set as the sole confirming method for DNA microarray results.

\section{MATERIALS AND METHODS}

Plant culture conditions and chitin oligomer treatments.

Arabidopsis seeds were sterilized and grown hydroponically according to Zhang and associates (2002). Seedlings (14-dayold) were treated with either purified chitooctaose (Octa-Nacetylchitooctaose; Sigma, St. Louis) or chitotetraose (TetraN-Aceytlchitotetraose; Seikagaku Corporation, Tokyo) at a final concentration of $1 \mu \mathrm{M}$ for the time indicated. The control seedlings were similarly treated with an equal amount of water.

\section{RNA extraction, DNase treatments, and RT-PCR.}

Total RNA was isolated from the collected seedlings using Trizol Reagent (Invitrogen, Carlsbad, CA, U.S.A.) and subsequently purified using an RNeasy mini kit (Qiagen, Inc., Valencia, CA, U.S.A.) according to the manufacturers' instructions. Purified RNA $(10 \mu \mathrm{g})$ was further treated with TURBO DNase (Ambion, Austin, TX, U.S.A.) to remove any contaminating genomic DNA, according to the manufacturer's instruc- tion. Approximately $1.5 \mu \mathrm{g}$ of DNA-free RNA was used for first-strand cDNA synthesis using the SuperScript III firststrand synthesis system for RT-PCR (Invitrogen) according to the manufacturer's instruction. For use in the high-throughput qRT-PCR reactions, the RT reactions were performed with $\mathrm{Su}$ perScript III RT (Invitrogen). The cDNAs used for the kinetic analysis of the TF expression after chitin treatments were obtained after reverse transcription of $2 \mu \mathrm{g}$ of RNA by M-MLV (Promega, Madison, WI, U.S.A.).

DNase treatment and cDNA synthesis quality were carefully monitored. The level of genomic DNA contamination was analyzed by qRT-PCR using primers designed to amplify the intron sequence of the AT5G65080 gene (5'-TTTTTTGCCCC CTTCGAATC-3' and 5'-ATCTTCCGCCACCACATTGTAC$\left.3^{\prime}\right)$. To verify the quality of the RT reactions, qRT-PCR amplification with primers designed to amplify $5^{\prime}$ (5'-TCTCG ATCTCAATTTCGCAAAA-3' and 5'-CGAAACCGTTGATT CCGATTC-3') and $3^{\prime}$ (5'-TTGGTGACAACAGGTCAAGCA$3^{\prime}$ and 5'-AAACTTGTCGCTCAATGCAATC-3') regions of GADPH cDNA were performed. The 3' to 5' transcription ratio was $>1.5$ and $<2$ for all the samples analyzed.

\section{qRT-PCR reaction conditions and data analysis.}

The 2,297 primer sequences of the 2,227 TF genes and the primer sequences of the $34 \mathrm{TF}$ genes and the nine ubiquitinligase genes analyzed by qPCR reactions are available in Supplemental Table VII. The high-throughput qRT-PCR screen was conducted at the Max Planck Institute of Molecular Plant Physiology, Gölm, Germany. The analysis of other genes, at different timepoints and in different conditions was performed at University of Missouri (Columbia, U.S.A.).

The qRT-PCR reactions were performed at Gölm in a 384well plate format (7900 HT sequence detection system; Applied Biosystems, Foster City, CA, U.S.A.). The reaction setup was done on the robot Evolution P3 liquid handling system (Perkin Elmer, Wellesley, MA, U.S.A.). The qRT-PCR reactions were performed at the University of Missouri with a 96well plate qRT-PCR machine (7500 real-time PCR system; Applied Biosystems). SYBR green PCR master mix (Applied Biosystems) was used to monitor cDNA synthesis. Primer sets (final concentration of $0.2 \mu \mathrm{M}$ for each primer) were used for a final volume of $10 \mu \mathrm{l}$. The thermal profile of the qRT-PCR reactions was: $50^{\circ} \mathrm{C}$ for $2 \mathrm{~min}, 95^{\circ} \mathrm{C}$ for $10 \mathrm{~min}, 40$ cycles of $95^{\circ} \mathrm{C}$ for $15 \mathrm{~s}$, and $60^{\circ} \mathrm{C}$ for $1 \mathrm{~min}$. Moreover, to analyze the quality of the dissociation curves, the following program was added after the 40 PCR cycles: $95^{\circ} \mathrm{C}$ for $15 \mathrm{~s}$, followed by a constant increase of the temperature from $60^{\circ} \mathrm{C}$ to $95^{\circ} \mathrm{C}$. The data were analyzed with two different software packages. The qRT-PCR results were analyzed with SDS 2.2.1 software (Applied Biosystems). An Rn threshold of 0.2 was selected to obtain the cycle threshold $(\mathrm{Ct})$ values (automatic background subtraction). PCR efficiencies (Peff) were calculated according to a linear regression analysis with LinRegPCR software (Ramakers et al. 2003). Only primer efficiencies were used to calculate the expression level of the genes if $R^{2}>0.995$ and Peff $>1.5$.

The expression of the $A T 2 G 28390$ (SAND family protein) gene was used to normalize all the qRT-PCR results due to its highly stable expression (Czechowski et al. 2005). The AT2G28390 Ct value was subtracted from the $\mathrm{Ct}$ values of the TF genes analyzed $(\Delta \mathrm{Ct})$. Expression levels (Exp) of each $\mathrm{TF}$ gene were calculated according to the equation $\operatorname{Exp}=\operatorname{Peff}^{(-\Delta \mathrm{Ct})}$.

Three biological replicates for each treatment were analyzed. A Student $t$-test was used to compare statistically the gene expression after two different treatments. The expression level ratio between two conditions with $P$ values $<0.05$ (95\% confidence) are taken into consideration in this study. 


\section{Microarray experiment and data analysis.}

Three biological replicates were analyzed for each condition. Total RNA $(7 \mu \mathrm{g})$, purified using an RNeasy mini kit (Qiagen Inc.), was used with the Affymetrix GeneChip expression 3'amplification reagenes one-cycle cDNA synthesis system (Affymetrix, Santa Clara, CA, U.S.A.) to synthesize doublestranded cDNA according to the manufacturer's instructions. The synthesized cDNA was purified using the Affymetrix GeneChip sample cleanup module and was used with the Affymetrix GeneChip IVT labeling system to synthesize biotinlabeled cRNA. The purified biotin-labeled cRNA was fragmented according to the manufacturer's instructions. The arrays were hybridized, washed, and scanned, also according to the manufacturer's instructions.

The scanned data (CEL or DAT files) were analyzed using the dChip (DNA-Chip Analyzer) software (version release, April 1, 2005) (Li and Wong 2001a and b). The default settings were used in the normalization and model-based data analysis, with the following criteria selected for identifying significantly regulated genes: twofold, with a $t$-test $P$ value $<0.05$, and the absolute signal intensity difference between a baseline and its corresponding treatment $>100$.

\section{ACKNOWLEDGMENTS}

We thank the DNA Core Facility (University of Missouri, Columbia, U.S.A.) for conducting the microarray hybridization and Y. Gibbon (MaxPlanck Institute of Molecular Plant Physiology) for design and optimization of pipetting robot programs. We thank S. Sachdev and T. Mayabb for critical reading of the manuscript. The work was funded by a grant to $\mathrm{G}$. Stacey from the United States Department of Energy, Energy Biosciences Program, Office of Basic Energy Sciences (grant number DE-FG0202ER15309).

\section{LITERATURE CITED}

Baureithel, K., Felix, G., and Boller, T. 1994. Specific, high affinity binding of chitin fragments to tomato cells and membranes. Competitive inhibition of binding by derivatives of chitooligosaccharides and a Nod factor of rhizobium. J. Biol. Chem. 269:17931-17938.

Bindschedler, L. V., Whitelegge, J. P., Millar, D. J., and Bolwell, G. P. 2006. A two component chitin-binding protein from French bean-Association of a proline-rich protein with a cysteine-rich polypeptide. FEBS (Fed. Eur. Biochem. Soc.) Lett. 580:1541-1546.

Boter, M., Ruiz-Rivero, O., Abdeen, A., and Prat, S. 2004. Conserved MYC transcription factors play a key role in jasmonate signaling both in tomato and Arabidopsis. Genes Dev. 18:1577-1591.

Cabrera, J. C., Messiaen, J., Cambier, P., and Van Cutsem, P. 2006. Size, acetylation and concentration of chitooligosaccharide elicitors determine the switch from defense involving PAL activation to cell death and water peroxide production in Arabidopsis cell suspensions. Physiol. Plant 127:44-56.

Czechowski, T., Bari, R. P., Stitt, M., Scheible, W. R., and Udvardi, M. K. 2004. Real-time RT-PCR profiling of over 1400 Arabidopsis transcription factors: Unprecedented sensitivity reveals novel root- and shootspecific genes. Plant J. 38:366-379.

Czechowski, T., Stitt, M., Altmann, T., Udvardi, M. K., and Scheible, W. R. 2005. Genome-wide identification and testing of superior reference genes for transcript normalization in Arabidopsis. Plant Physiol. 139:517.

Day, R. B., Okada, M., Ito, Y., Tsukada, K., Zaghouani, H., Shibuya, N., and Stacey, G. 2001. Binding site for chitin oligosaccharides in the soybean plasma membrane. Plant Physiol. 126:1162-1173.

Day, R. B., Shibuya, N., and Minami, E. 2003. Identification and characterization of two new members of the GRAS gene family in rice responsive to $N$-acetylchitooligosaccharide elicitor. Biochim. Biophys. Acta 1625:261-268

Day, R. B., Tanabe, S., Koshioka, M., Mitsui, T., Itoh, H., UeguchiTanaka, M., Matsuoka, M., Kaku, H., Shibuya, N., and Minami, E. 2004. Two rice GRAS family genes responsive to $N$-acetylchitooligosaccharide elicitor are induced by phytoactive gibberellins: Evidence for cross-talk between elicitor and gibberellin signaling in rice cells. Plant Mol. Biol. 54:261-272.

Desveaux, D., Marechal, A., and Brisson, N. 2005. Whirly transcription factors: Defense gene regulation and beyond. Trends Plant Sci. 10:95102.

Devoto, A., Muskett, P. R., and Shirasu, K. 2003. Role of ubiquitination in the regulation of plant defence against pathogens. Curr. Opin. Plant Biol. 6:307-311.

Diaz, C. L., Spaink, H. P., and Kijne, J. W. 2000. Heterologous rhizobial lipochitin oligosaccharides and chitin oligomers induce cortical cell divisions in red clover roots, transformed with the pea lectin gene. Mol. Plant-Microbe Interact. 13:268-276.

Dinesh-Kumar, S. P., and Baker, B. J. 2000. Alternatively spliced N resistance gene transcripts: Their possible role in tobacco mosaic virus resistance. Proc. Natl. Acad. Sci. U.S.A. 97:1908-1913.

Eulgem, T. 2005. Regulation of the Arabidopsis defense transcriptome. Trends Plant Sci. 10:71-78.

Eulgem, T., Rushton, P. J., Schmelzer, E., Hahlbrock, K., and Somssich, I. E. 1999. Early nuclear events in plant defence signalling: Rapid gene activation by WRKY transcription factors. EMBO (Eur. Mol. Biol. Organ.) J. 18:4689-4699.

Eulgem, T., Rushton, P. J., Robatzek, S., and Somssich, I. E. 2000. The WRKY superfamily of plant transcription factors. Trends Plant Sci. 5:199-206.

Felix, G., Regenass, M., and Boller, T. 1993. Specific perception of subnanomolar concentrations of chitin fragments by tomato cells: Induction of extracellular alkalinization, changes in protein phosphorylation, and establishment of a refractory state. Plant J. 4:307-316.

Felix, G., Baureithel, K., and Boller, T. 1998. Desensitization of the perception system for chitin fragments in tomato cells. Plant Physiol. 117:643-650.

Felix, G., Duran, J. D., Volko, S., and Boller, T. 1999. Plants have a sensitive perception system for the most conserved domain of bacterial flagellin. Plant J. 18:265-276.

Gomez-Gomez, L. 2004. Plant perception systems for pathogen recognition and defence. Mol. Immunol. 41:1055-1062.

Gutterson, N., and Reuber, T. L. 2004. Regulation of disease resistance pathways by AP2/ERF transcription factors. Curr. Opin. Plant Biol. 7:465-471.

Halterman, D. A., Wei, F., and Wise, R. P. 2003. Powdery mildew-induced Mla mRNAs are alternatively spliced and contain multiple upstream open reading frames. Plant Physiol. 131:558-567.

Heath, M. C. 2000. Nonhost resistance and nonspecific plant defenses. Curr. Opin. Plant Biol. 3:315-319.

Hui, D., Iqbal, J., Lehmann, K., Gase, K., Saluz, H. P., and Baldwin, I. T. 2003. Molecular interactions between the specialist herbivore Manduca sexta (lepidoptera, sphingidae) and its natural host Nicotiana attenuata: V. microarray analysis and further characterization of large-scale changes in herbivore-induced mRNAs. Plant Physiol. 131:1877-1893.

Johnson, E. T., and Dowd, P. F. 2004. Differentially enhanced insect resistance, at a cost, in Arabidopsis thaliana constitutively expressing a transcription factor of defensive metabolites. J. Agric. Food Chem. 52:5135-5145.

Journot-Catalino, N., Somssich, I. E., Roby, D., and Kroj, T. 2006. The transcription factors WRKY11 and WRKY17 act as negative regulators of basal resistance in Arabidopsis thaliana. Plant Cell 18:3289-3302.

Kaku, H., Nishizawa, Y., Ishii-Minami, N., Akimoto-Tomiyama, C., Dohmae, N., Takio, K., Minami, E., and Shibuya, N. 2006. Plant cells recognize chitin fragments for defense signaling through a plasma membrane receptor. Proc. Natl. Acad. Sci. U.S.A. 18:11086-11091.

Kim, C. Y., Lee, S. H., Park, H. C., Bae, C. G., Cheong, Y. H., Choi, Y. J., Han, C., Lee, S. Y., Lim, C. O., and Cho, M. J. 2000. Identification of rice blast fungal elicitor-responsive genes by differential display analysis. Mol. Plant Microbe Interact. 13:470-474.

Kim, C. Y., and Zhang, S. 2004. Activation of a mitogen-activated protein kinase cascade induces WRKY family of transcription factors and defense genes in tobacco. Plant J. 38:142-151.

Li, C., and Wong, W. H. 2001a. Model-based analysis of oligonucleotide arrays: Expression index computation and outlier detection. Proc. Natl. Acad. Sci. U.S.A. 98:31-36.

Li, C., and Wong, W. H. 2001b. Model-based analysis of oligonucleotide arrays: Model validation, design issues and standard error application. Genome Biology 2: research0032.1-0032.11. Published online.

Li, J., Li, X., Guo, L., Lu, F., Feng, X., He, K., Wei, L., Chen, Z., Qu, L. J., and Gu, H. 2006. A subgroup of MYB transcription factor genes undergoes highly conserved alternative splicing in Arabidopsis and rice. J. Exp. Bot. 57:1263-1273.

Liu, Y., Schiff, M., Serino, G., Deng, X. W., and Dinesh-Kumar, S. P. 2002. Role of SCF ubiquitin-ligase and the COP9 signalosome in the $\mathrm{N}$ gene-mediated resistance response to Tobacco mosaic virus. Plant Cell 14:1483-1496.

Liu, Y., Schiff, M., and Dinesh-Kumar, S. P. 2004. Involvement of MEK1 MAPKK, NTF6 MAPK, WRKY/MYB transcription factors, COI1 and 
CTR1 in $N$-mediated resistance to tobacco mosaic virus. Plant $\mathrm{J}$. 38:800-809

Liu, X. Q., Bai, X. Q., Qian, Q., Wang, X. J., Chen, M. S., and Chu, C. C. 2005. OsWRKY03, a rice transcriptional activator that functions in defense signaling pathway upstream of OsNPR1. Cell Res. 15:593-603.

Lorenzo, O., Chico, J. M., Sanchez-Serrano, J. J., and Solano, R. 2004. JASMONATE-INSENSITIVE1 encodes a MYC transcription factor essential to discriminate between different jasmonate-regulated defense responses in Arabidopsis. Plant Cell 16:1938-1950.

McGrath, K. C., Dombrecht, B., Manners, J. M., Schenk, P. M., Edgar, C. I., Maclean, D. J., Scheible, W. R., Udvardi, M. K., and Kazan, K. 2005. Repressor- and activator-type ethylene response factors functioning in jasmonate signaling and disease resistance identified via a genome-wide screen of Arabidopsis transcription factor gene expression. Plant Physiol 139:949-959.

Navarro, L., Zipfel, C., Rowland, O., Keller, I., Robatzek, S., Boller, T., and Jones, J. D. 2004. The transcriptional innate immune response to flg22. Interplay and overlap with Avr gene-dependent defense responses and bacterial pathogenesis. Plant Physiol. 135:1113-1128.

Nürnberger, T., Brunner, F., Kemmerling, B., and Piater, L. 2004. Innate immunity in plants and animals: Striking similarities and obvious differences. Immunol. Rev. 198:249-266.

Park, C. J., Shin, Y. C., Lee, B. J., Kim, K. J., Kim, J. K., and Paek, K. H. 2006. A hot pepper gene encoding WRKY transcription factor is induced during hypersensitive response to Tobacco mosaic virus and Xanthomonas campestris. Planta 223:168-179.

Ramakers, C., Ruijte, J. M., Deprez, R. H., and Moorman, A. F. 2003. Assumption-free analysis of quantitative real-time polymerase chain reaction (PCR) data. Neurosci. Lett. 339:62-66.

Ramonell, K. M., Zhang, B., Ewing, R. M., Chen, Y., Xu, D., Stacey, G., and Somerville, S. 2002. Microarray analysis of chitin elicitation in Arabidopsis thaliana. Mol. Plant Pathol. 3:301-311.

Ramonell, K., Berrocal-Lobo, M., Koh, S., Wan, J., Edwards, H., Stacey, G., and Somerville, S. 2005. Loss-of-function mutations in chitin responsive genes show increased susceptibility to the powdery mildew pathogen Erysiphe cichoracearum. Plant Physiol 138:1027-1036.

Ryu, H. S., Han, M., Lee, S. K., Cho, J. I., Ryoo, N., Heu, S., Lee, Y. H., Bhoo, S. H., Wang, G. L., Hahn, T. R., and Jeon, J. S. 2006. A comprehensive expression analysis of the WRKY gene superfamily in rice plants during defense response. Plant Cell Rep. 25:836-47

Schmelz, E. A., Alborn, H. T., and Tumlinson, J. H. 2003. Synergistic interactions between volicitin, jasmonic acid and ethylene mediate insectinduced volatile emission in Zea mays. Physiol. Plant 117:403-412.

Shibuya, N., and Minami, E. 2001. Oligosaccharide signaling for defense responses in plant. Physiol. Mol. Plant Pathol. 59:223-233.

Snaar-Jagalska, B. E., Krens, S. F. G., Robina, I., Wang, L. X., and Spaink, H. P. 2003. Specific activatin of ERK pathways by chitin oligosaccharides in embryonic zebrafish cell lines. Glycobiology 13:725-732.

Stacey, G., and Shibuya, N. 1997. Chitin recognition in rice and legumes. Plant Soil 194:161-169.
Stacey, G., Libault, M., Brechenmacher, L., Wan, J., and May, G. D. 2006. Genetics and functional genomics of legume nodulation. Curr. Opin. Plant Biol. 9:110-121.

Tanabe, S., Okada, M., Jikumaru, Y., Yamane, H., Kaku, H., Shibuya, N., Minami, E. 2006. Induction of resistance against rice blast fungus in rice plants treated with a potent elicitor, $N$-acetylchitooligosaccharide. Biosci. Biotechnol. Biochem. 70(7):1599-1605.

Thurow, C., Schiermeyer, A., Krawczyk, S., Butterbrodt, T., Nickolov, K., and Gatz, C. 2005. Tobacco bZIP transcription factor TGA2.2 and related factor TGA2.1 have distinct roles in plant defense responses and plant development. Plant J. 44:100-113.

Vailleau, F., Daniel, X., Tronchet, M., Montillet, J. L., Triantaphylides, C., and Roby, D. 2002. A R2R3-MYB gene, AtMYB30, acts as a positive regulator of the hypersensitive cell death program in plants in response to pathogen attack. Proc. Natl. Acad. Sci. U.S.A. 99:10179-10184.

Vierstra, R. D. 2003. The ubiquitin/26S proteasome pathway, the complex last chapter in the life of many plant proteins. Trends Plant Sci. 8:135142.

Wan, J., Zhang, S., and Stacey, G. 2004. Activation of a mitogen-activated protein kinase pathway in Arabidopsis by chitin. Mol. Plant Pathol. 5:125-135.

Xu, X., Chen, C., Fan, B., and Chen, Z. 2006. Physical and functional interactions between pathogen-induced Arabidopsis WRKY18, WRKY40, and WRKY60 transcription factors. Plant Cell. 18:13101326.

Yanagisawa, S. 2002. The Dof family of plant transcription factors. Trends Plant Sci. 7:555-560.

Yang, Y., and Klessig, D. F. 1996. Isolation and characterization of a Tobacco mosaic virus-inducible myb oncogene homolog from tobacco. Proc. Natl. Acad. Sci. U.S.A. 93:14972-14977.

Yang, C. W., Gonzalez-Lamothe, R., Ewan, R. A., Rowland, O., Yoshioka, H., Shenton, M., Ye, H., O’Donnell, E., Jones, J. D., and Sadanandom, A. 2006. The E3 ubiquitin ligase activity of Arabidopsis plant UBOX17 and its functional tobacco homolog ACRE276 are required for cell death and defense. Plant Cell 18:1084-1098.

Zhang, B., Ramonell, K., Somerville, S., and Stacey, G. 2002. Characterization of early, chitin-induced gene expression in Arabidopsis. Mol. Plant Microbe Interact. 15:963-970.

Zheng, Z., Qamar, S. A., Chen, Z., and Mengiste, T. 2006. Arabidopsis WRKY33 transcription factor is required for resistance to necrotrophic fungal pathogens. Plant J. 48:592-605.

Zipfel, C., Robatzek, S., Navarro, L., Oakeley, E. J., Jones, J. D., Felix, G., and Boller, T. 2004. Bacterial disease resistance in Arabidopsis through flagellin perception. Nature 428:764-776.

\section{AUTHOR RECOMMENDED INTERNET RESOURCE}

National Center for Biotechnology Information website: www.ncbi.nlm.nih.gov/geo 